\title{
Case Files of the New York City Poison Control Center: Antidotal strategies for the Management of Methotrexate toxicity
}

\author{
Silas W. Smith, MD ${ }^{a, b}$, Lewis S. Nelson, MD ${ }^{a, b}$
}

aNew York City Poison Control Center, New York, NY

bNew York University School of Medicine, New York, NY

\section{CASE PRESENTATION}

A 10 -year-old boy $\left(37.5 \mathrm{~kg}\right.$; body surface area $\left.1.26 \mathrm{~m}^{2}\right)$ with osteosarcoma of the right humerus received a planned 4-hour infusion of high-dose methotrexate $\left(16 \mathrm{~g}, 12.7 \mathrm{~g} / \mathrm{m}^{2}\right)$. His previous medical history was notable for an implanted central venous catheter placement complicated by Horner's syndrome. Renal and hepatic functions were normal at baseline. A postinfusion methotrexate concentration was uninterpretable, but the significance of this result was not initially appreciated by the treating clinicians. Over the next 48 hours, the child developed blurry vision, painful mucositis, stomatitis, and facial blistering. Reported vital signs were: BP, 121/82 mm Hg; pulse, 111/minute; respirations, 16/minute. A physical examination was consistent with the reported symptoms. The 48-hour postinfusion serum methotrexate concentration at the time of poison control center (PCC) consultation was $171 \mu \mathrm{mol} / \mathrm{L}$ (Figure 1).

\section{What is methotrexate (amethopterin) and how is it used?}

Methotrexate (MTX) is a folate analogue antimetabolite commonly used in treating blood and solid organ malignancies, dermatological and rheumatic diseases, and in termination of gestation. When first introduced as chemotherapeutic agents, folic acid conjugates produced an accelerated progression in the bone marrow and viscera of children with acute leukemia, suggesting treatment options with folate antagonists. Subsequently, the antifolate aminopterin (4-aminopteroyl-glutamic acid) produced the first reported clinical success in inducing temporary remission in acute leukemia in 1948 [1]. Aminopterin's significant

toxic side effects spurred a search for alternative antifolate agents with a broader therapeutic window, and led to aminopterin's substitution by MTX (amethopterin) [2-4]. MTX later provided the first medical cure of a solid cancer [5].

The FDA approved MTX for use in psoriasis in 1971, and it found additional use in the treatment of dermatomyositis, pemphigus and pemphigoid, and pityriasis rubra pilaris [6]. One of several disease-modifying antirheumatic drugs (DMARDs), MTX received an FDA indication for use in adults with severe, active rheumatoid arthritis in 1988 with extension to children with active polyarticular-course juvenile rheumatoid arthritis [7]. A 1982 report first described the use of MTX in the treatment of interstitial ectopic pregnancy [8]. Since then, MTX has become an accepted abortive medical therapy for ectopic gestations [9]. MTX is also used off-label in combination with misoprostol for elective medical termination of pregnancy [10]. MTX provides prophylaxis against graft-versus-host disease, particularly in allogeneic stem cell transplantation with peripheral-blood stem cells or bone marrow $[11,12]$.

\section{How is methotrexate dosed?}

Methotrexate may be administered via intramuscular (IM), intrathecal (IT), intravenous (IV), or oral (PO) routes. Dosing is quite diverse due to the significant variations in MTX indication. High-dose methotrexate (HDMTX) for chemotherapy, which requires leucovorin rescue, is MTX, $1 \mathrm{~g} / \mathrm{m}^{2} \mathrm{IV}$ [13]. Lower doses may be used in alternative chemotherapeutic regimens, while up to $8-12 \mathrm{~g} / \mathrm{m}^{2}$ or more may be given for osteosarcoma, leukemia, and lymphoma [14-16]. IT MTX is more appropriately dosed by age, as a fixed dose per $\mathrm{m}^{2}$ was reported to result in low

Keywords: carboxypeptidase $\mathrm{G}_{2}$, folate, leucovorin, methotrexate, nephrotoxicity

Notes: No outside funding was received.

Corresponding Author: Silas W. Smith, MD, New York City Poison Control Center, 455 First Avenue, Room 123, New York, NY 10016. Phone: (212) 746-7667. Fax: (212) 447-8223. Email: smiths11@med.nyu.edu 


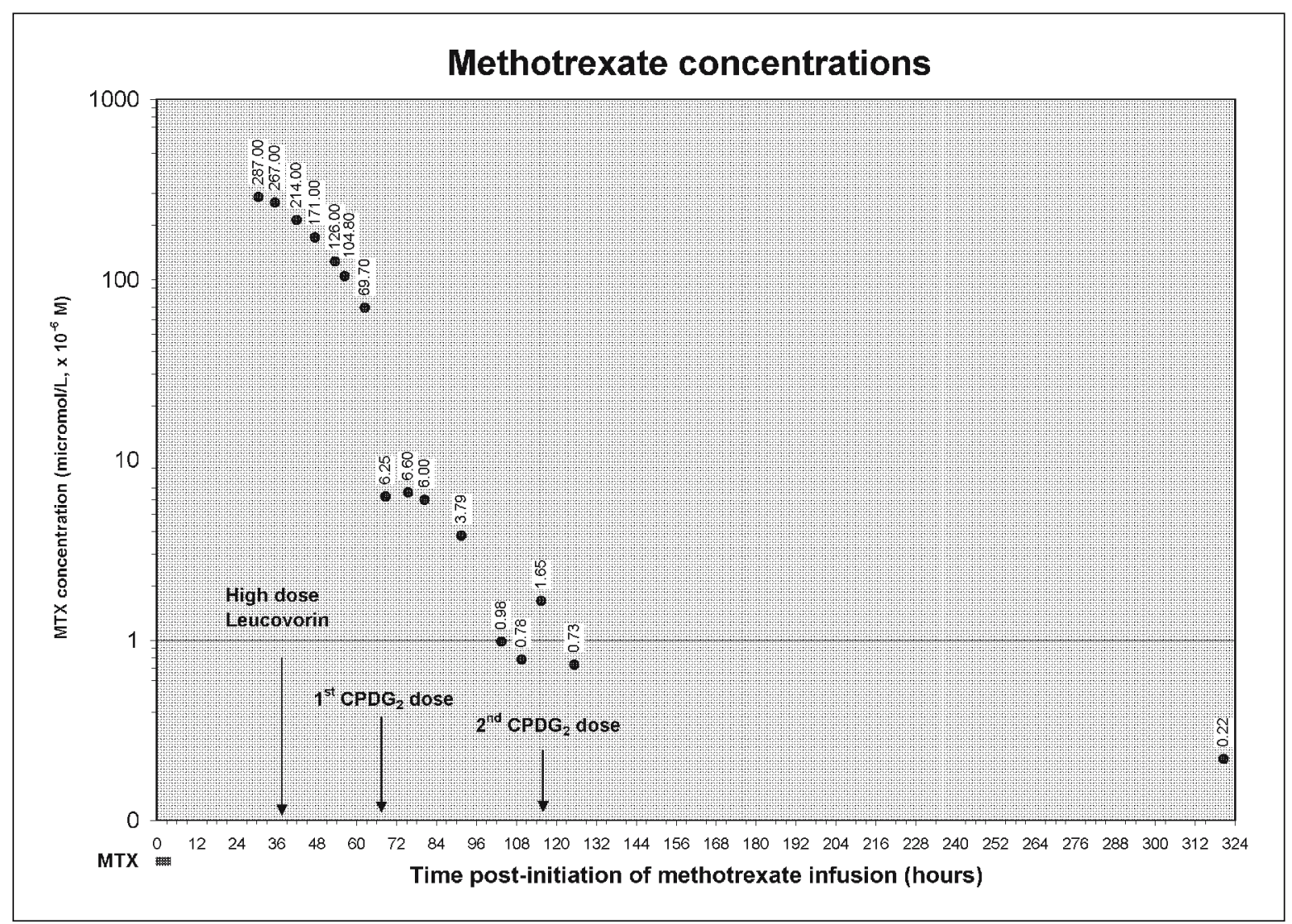

Figure 1: Methotrexate infusion (solid line), serum MTX concentrations by immunoassay (circles), and high-dose leucovorin $\left(1500 \mathrm{mg} / \mathrm{m}^{2}\right)$ and $\mathrm{CPDG}_{2}$ administration (arrows).

cerebrospinal fluid (CSF) methotrexate concentrations and reduced efficacy in children, and in high concentrations and neurotoxicity in adults $[17,18]$. Psoriasis patients are normally provided MTX 7.5-30 mg PO weekly [19]. Rheumatoid arthritis treatment similarly involves MTX 7.5-20 mg PO weekly [20]. Multiple fatalities and serious adverse events have resulted from prescription, dispensing, administration, and patient errors in which the intended weekly dose was incorrectly consumed daily $[21,22]$. For termination of ectopic pregnancy, MTX $50 \mathrm{mg} / \mathrm{m}^{2} \mathrm{IM}$ is commonly used [9]. In elective termination of pregnancy, MTX $25-75 \mathrm{mg} / \mathrm{m}^{2} \mathrm{IM}$ or $25-50 \mathrm{mg}$ PO in combination with misoprostol are employed [10].

\section{How is methotrexate metabolized?}

Intracellularly, folypolyglutamyl synthase adds gamma-linked glutamate groups to MTX [23]. Polyglutamation increases the intracellular half-life of MTX, allowing it to persist despite extracellular MTX elimination or removal [24]. MTX can also be hydroxylated at the 7-position by hepatocyte aldehyde oxidase to yield 7-OH-MTX [14]. In the gut, bacterial carboxypeptidase converts MTX to 4-amino-4-deoxy-10-methylpteroic acid (DAMPA) [24].

\section{What are the pharmacokinetics of methotrexate?}

Methotrexate is a weak acid with a $\mathrm{pK}_{\mathrm{a}}$ of $4.8-5.5$, thus is ionized at physiological $\mathrm{pH}$ [14]. About 50\% protein binding occurs, regardless of serum concentration [25]. Route of administration and dose can significantly alter MTX kinetics. With oral administration, absorption of MTX appears saturable, with a plateau achieved between 25-50 mg [19]. Thus, near-complete intestinal uptake occurs at doses $<30 \mathrm{mg}$, while plasma MTX concentrations achieved after PO administration $\geq 80 \mathrm{mg}$ are less than $10 \%$ that given IV [14]. Renal elimination of MTX occurs by passive glomerular filtration and associated active tubular reabsorption and secretion [26]. Due to individual differences in elimination, 3-fold variations in serum MTX concentrations were seen with administration of $1 \mathrm{~g} / \mathrm{m}^{2} \mathrm{IV}$ [16]. Reported adult clearances of MTX and 7-OH-MTX are 99.1-156.7 ml/minute and $33.3 \mathrm{ml} /$ minute [26-28]. Statistically significant differences in steady-state MTX clearance were seen in infants aged 0-6 months compared to infants $7-12$ months $\left(89 \pm 32 \mathrm{ml} / \mathrm{minute} / \mathrm{m}^{2}\right.$ versus $111 \pm 40 \mathrm{ml} / \mathrm{minute} / \mathrm{m}^{2}$ ) [29]. Median MTX late elimination phase half-life was reported as 4.02 hours in osteosarcoma patients receiving $12 \mathrm{~g} / \mathrm{m}^{2} \mathrm{IV}$, with wide variability [27]. In contrast, pediatric patients receiving weekly low-dose oral MTX 
(2.1-22.3 mg/m²) had a median elimination half-life of 1.7 hours. Nonsteroidal anti-inflammatory drugs, barbiturates, salicylates, sulfonamides, penicillin, benzimidazoles, and probenecid can all increase MTX concentrations, and glomerular impairment is a main factor in increasing the MTX elimination time [19, 26,30]. Of note, IT MTX can enter the systemic circulation from bulk flow CSF absorption and possibly by active transport to produce a systemic exposure 1.7 times that of an equivalent oral dose [31].

\section{What is methotrexate's mechanism of action?}

Folate (vitamin $\mathrm{B}_{9}$ ) must be activated prior to its extensive utilization in the 1-carbon metabolic pathways necessary for DNA and RNA synthesis (Figure 2). Folate is first reduced by dihydrofolate reductase to dihydrofolate $\left(\mathrm{FH}_{2}\right)$, and then again by dihydrofolate reductase to yield "active" tetrahydrofolate $\left(\mathrm{FH}_{4}\right)$. $\mathrm{FH}_{4}$ obtains one carbon from serine to form 5,10-methylene- $\mathrm{FH}_{4}$. Thymidylate synthase then utilizes 5,10 -methylene- $\mathrm{FH}_{4}$ to produce deoxythymidine monophosphate (dTMP) for DNA synthesis from deoxyuridine monophosphate (dUMP). In the process, 5,10-methylene- $\mathrm{FH}_{4}$ is converted back to $\mathrm{FH}_{2}$ for reuse. 5,10methylene- $\mathrm{FH}_{4}$ or $\mathrm{FH}_{4}$ can be converted to 10 -formyl- $\mathrm{FH}_{4}$ to drive two independent steps in purine ring synthesis (conversion of glycinamide ribonucleotide [GAR] to formylglycinamide ribonucleotide [FGAR] and conversion of 5-aminoimidazole-4carboxamide ribonucleotide [AICAR] to 5-formyl-AICAR [FAICAR]) [32]. 5-formyl- $\mathrm{FH}_{4}$ (leucovorin, folinic acid) is least susceptible to oxidative degradation and is the most stable natural form of reduced folate [33].

MTX antagonizes folate along multiple intracellular pathways (Figure 2). MTX enters the cell either by folate transmembrane transporters or in high doses by passive diffusion [24]. Subsequently, MTX and its polyglutamated metabolites competitively inhibit dihydrofolate reductase such that neither $\mathrm{FH}_{2}$ nor active $\mathrm{FH}_{4}$ can be generated from folate, nor can existing $\mathrm{FH}_{2}$ be recycled. Purine ring synthesis is impaired by several means. MTX and polyglutamated MTX block the participating enzymes amidophospho-ribosyltransferase (PPAT) and 5-aminoimidazole4-carboxamide ribonucleotide transformylase (AICART) [24,34]. Substrate depletion of 10 -formyl- $\mathrm{FH}_{4}$ as a consequence of depleted $\mathrm{FH}_{4}$ would impair the GAR-FGAR and AICAR-FAICAR conversion. Additionally, the inhibition by MTX and its polyglutamated metabolites of thymidylate synthase (TYMS - the same enzyme target of the antimetabolite fluorouracil) further compromises thymidine synthesis $[23,35]$. Furthermore, MTX has complex dose-dependent effects on deoxycytidine kinase, a separate nucleoside salvage-pathway enzyme, with inhibition at low nucleoside concentrations and enhancement at high nucleoside concentrations [36].

As a consequence of these multiple mechanisms, MTX affects rapidly proliferating cells (e.g., malignancies and those in the gastrointestinal tract, bone marrow or skin) that rely heavily on de novo nucleotide creation for DNA replication and RNA synthesis. Because of its ability to impair cellular replication, MTX use expanded beyond conventional chemotherapy regimens (e.g., breast carcinoma, choriocarcinoma, lymphoma, and osteosarcoma) to include treatment of nonneoplastic conditions with significant cellular proliferative such as psoriasis, rheumatoid arthritis, and ectopic pregnancy. In the lower doses used in rheumatic disease, increased adenosine concentrations as a consequence of AICART inhibition may underlie MTX's anti-inflammatory and antiproliferative effects on activated lymphocytes [20].

\section{How does methotrexate poisoning with "therapeutic dosing" occur?}

Methotrexate's primary route of elimination is renal. Patients with impaired renal function are therefore at increased risk of developing MTX poisoning, although elevated concentrations can occur in the absence of preexisting renal disease. Concurrent administration of nephrotoxic agents, including intravenous contrast, can also induce MTX toxicity [37]. A literature and clinical trials review of high-dose MTX for osteosarcoma reported nephrotoxicity (creatinine $\geq 1.5 \mathrm{mg} / \mathrm{dL}[132.6 \mu \mathrm{mol} / \mathrm{L}]$ ) in $1.8 \%$ of patients $(68 / 3887)$ with a range of $0-12 \%$ across the studies examined [13]. Mortality was $4.4 \%$ (4/68) in those with nephrotoxicity. Similarly, in 264 children receiving MTX 5 or $8 \mathrm{~g} / \mathrm{m}^{2}$, $3.8 \%$ had delayed elimination of MTX greater than 120 hours [30]. DAMPA and 7-OH-MTX are 10 times and 4 times less soluble than MTX in urine, respectively $[13,14]$. Precipitation of these metabolites or MTX itself in the renal tubules may cause acute renal failure and tubular necrosis, further impairing MTX excretion and prolonging MTX exposure [15]. Additionally, individual genetic polymorphisms of folate-dependent enzymes AICART, glycine hydroxymethyl-transferase (GHMT), methylene tetrahydrofolate reductase (MTHFR), and TYMS are associated with neurological, gastrointestinal, and dermatological side effects [38].

\section{What clinical effects are expected from methotrexate toxicity? How is a patient with suspected toxicity evaluated?}

Organ systems with rapid cell turnover are most affected by persistently elevated serum MTX concentrations. Hematological abnormalities, particularly myelosuppression, may occur. Anemia and thrombocytopenia are also seen. Nonhematological effects commonly include stomatitis/mucositis, diarrhea, dermatitis, and hepatotoxicity [14]. Renal toxicity occurs by the mechanisms discussed previously. In one study that included adult patients aged $<60$ years, $>60$ years, and $>70$ years, increases in creatinine from 1.5-3.0 times normal appeared in 3\%, 8\% and $19 \%$, respectively, and creatinine $>3.1$ times normal developed in $2 \%, 7 \%$, and $5 \%$ [39]. Pulmonary findings occur in up to $10 \%$ of patients, and consist of acute interstitial pneumonitis, bronchiolitis obliterans organizing pneumonia, interstitial fibrosis, noncardiogenic pulmonary edema, pleuritis, pleural effusions, or pulmonary nodules $[40,41]$. Risk factors for MTX pulmonary toxicity in chemotherapy are the use of additional chemotherapeutic agents such as cyclophosphamide or bleomycin and the 


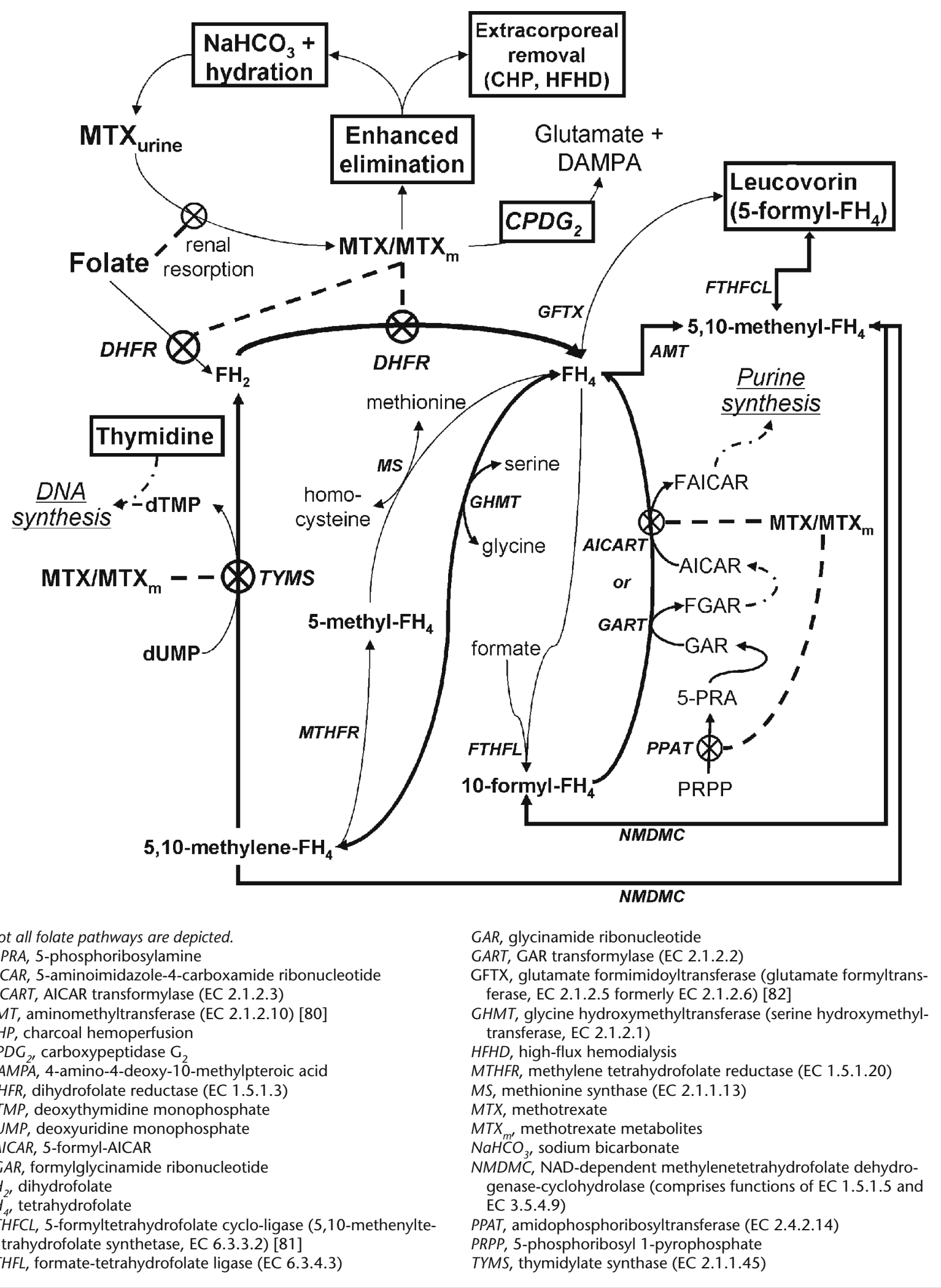

Figure 2: Folate metabolism, methotrexate antagonism $(-\otimes)$, and antidotal strategies (boxes). 
tapering of steroids; risk factors in oral low-dose therapy are older age, diabetes, previous use of DMARDs, rheumatoid pleuropulmonary involvement, and hypoalbuminemia [42,43]. Acute, subacute, and chronic neurotoxicity (after either high-dose IV or IT therapy) has been described. IT MTX can produce chemical arachnoiditis in 5-40\% of patients, with headache, nausea, vomiting, fever, back pain, and dizziness being prominent symptoms [44]. Days to weeks later, paraplegia, cerebellar dysfunction, cranial nerve palsies, and seizures may occur [45]. Particularly after combined treatment with cranial irradiation, a leukoencephalopathy characterized by confusion, somnolence, ataxia, spasticity seizures, coma, or death may arise after a course of months to years $[44,46,47] \mathrm{In}$ patients receiving up to $4 \mathrm{~g} / \mathrm{m}^{2} \mathrm{IV}$ MTX with whole-brain irradiation, $19.5 \%$ had brain MRI evidence of leukoencephalopathy and 7.1\% demonstrated clinical evidence of late neurotoxicity [39].

Any symptoms suggestive of the above processes should prompt a clinical evaluation, a serum methotrexate concentration, and laboratory assessment of renal, hematological, and hepatic function. Further diagnostic studies such as chest radiography or brain imaging may be indicated for pulmonary or neurological complaints.

\section{How does one interpret a reported methotrexate value?}

In order to assess therapeutic or potentially toxic concentrations, serum levels of MTX are routinely monitored by automated procedures such as fluorescence polarization immunoassay or enzyme-multiplied immunoassay. Due to the presence of metabolites, these assays may overestimate the MTX concentration in $2 \%$ and $5 \%$ of 42 -hour plasma samples and $3 \%$ and $31 \%$ of 66 hour plasma samples, respectively [48]. Some confusion in interpreting MTX concentrations arises from the fact that MTX may be reported variously in $\mu \mathrm{mol} / \mathrm{L}$ or $\mathrm{nmol} / \mathrm{L}$, in $\mu \mathrm{M}$ or $\mathrm{nM}$, or in exponential format (e.g., $\times 10^{-7} \mathrm{M}$ ). In patients receiving chemotherapy, 24-hour MTX concentrations $>10^{-5} \mathrm{M}$ (10 $\mu \mathrm{mol} / \mathrm{L})$, 48-hour concentrations $>10^{-6} \mathrm{M}(1 \mu \mathrm{mol} / \mathrm{L})$, or 72 -hour $>10^{-7} \mathrm{M}(0.1 \mu \mathrm{mol} / \mathrm{L}$ or $100 \mathrm{nM})$ are considered at high risk for toxicity [49]. Values of $<10^{-8} \mathrm{M}(10 \mathrm{nM})$ should be present in patients receiving MTX for other indications [19].

\section{CASE CONTINUATION}

The patient's creatinine had risen from $0.57 \mathrm{mg} / \mathrm{dL}(50.4 \mu \mathrm{mol} / \mathrm{L})$ preinfusion to $2.76 \mathrm{mg} / \mathrm{dL}(244 \mu \mathrm{mol} / \mathrm{L})$ at 42 hours postmethotrexate infusion. He developed abdominal pain requiring parenteral opioids. Aminotransferases rose to AST, $815 \mathrm{U} / \mathrm{L}$ and ALT, $1574 \mathrm{U} / \mathrm{L}$ with a total bilirubin of $3.5 \mathrm{mg} / \mathrm{dL}(59.85 \mu \mathrm{mol} / \mathrm{L})$.

\section{Would folate reverse the apparent toxicity?}

Folate is not an effective antidote because methotrexate blocks the enzymes responsible for folate activation and utilization. While folate will inhibit renal resorption of methotrexate, this is inadequate therapy.

\section{What antidotal strategies exist to treat methotrexate toxicity?}

Fluids resuscitation may be required to reverse volume depletion from gastrointestinal losses. Intravenous crystalloids sufficient to maintain brisk diuresis ( $>60 \mathrm{~mL} /$ hour) are also critical to maximizing methotrexate elimination. Urine alkalinization further improves urinary elimination of MTX [50]. Methotrexate's urinary precipitation is minimized in alkaline urine: at $\mathrm{pH}$ 7.5 MTX is 10 times more soluble than at pH $5.5[14,51]$. The beneficial effects of alkaline diuresis are seen even in patients with preexisting renal dysfunction [52]. Therefore, intravenous sodium bicarbonate should be routinely given in addition to aggressive hydration to maximize urinary solubility [53].

Leucovorin (5-formyl- $\mathrm{FH}_{4}$, folinic acid, citrovorum factor, calcium folinate) was first identified in 1948 as a required growth factor for deficient Leuconostoc citrovorum species [54]. Within 2 years it was reported to successfully reverse aminopterin and MTX toxicity, which had previously resisted folate rescue [55]. Leucovorin is a mixture of diastereoisomers of the 5-formyl derivative of tetrahydrofolic acid. The $l$-isomer is biologically and pharmacologically active, while the $d$-isomer is neither metabolized to any significant degree nor taken up in tissues [56]. Although leucovorin $20-40 \mathrm{mg}$ PO is bioequivalent or superior to IV administration because of reduced absorption of the inactive form and presystemic intestinal metabolism, at doses above $40 \mathrm{mg}$ PO, active intestinal transport is saturated $[57,58]$. Leucovorin sustains the folate cycle in bypassing the blocked dihydrofolate reductase pathways (Figure 2). The $10 \mathrm{mg} / \mathrm{m}^{2} \mathrm{IV}$ dose of leucovorin for normal chemotherapeutic "rescue" therapy must be increased significantly in patients with elevated MTX concentrations. Nomograms and established treatment protocols exist to guide therapy for elevated MTX concentrations at different time points [59]. Leucovorin IV doses of $100 \mathrm{mg} / \mathrm{m}^{2}$ or $1000 \mathrm{mg} / \mathrm{m}^{2}$ every 6 hours and as high as $10 \mathrm{~g} /$ day been used [60]. However, data suggest that at MTX concentrations above $100 \mu \mathrm{mol} / \mathrm{L}$, adequate leucovorin concentrations cannot be achieved for competitive reversal of toxicity $[15,61]$. In the event that a MTX concentration is unavailable, empiric leucovorin (molecular weight 511) should be administered to achieve a plasma molar concentration equal to or greater than that of the concentration estimated from the exposure to MTX (molecular weight 455). Leucovorin is continued until the serum MTX concentration is $<10 \mathrm{nmol} / \mathrm{L}(0.01 \mu \mathrm{mol} / \mathrm{L})$ in patients not receiving MTX for malignancy, or $<50-100 \mathrm{nmol} / \mathrm{L}(0.05-0.1 \mu \mathrm{mol} / \mathrm{L})$ in patients receiving MTX as chemotherapy [57]. Because of its calcium content (0.004 mEq calcium per mg of leucovorin), leucovorin infusion should not exceed $160 \mathrm{mg} /$ minute. Intrathecal administration of leucovorin is contraindicated and may be fatal $[62,63]$. When doses $>10 \mathrm{mg} / \mathrm{m}^{2}$ are administered, leucovorin should be reconstituted with sterile water.

Thymidine as a rescue agent ("thymidylate salvage") was available starting in 1978 under sponsorship of the National Cancer Institute (NCI) [64]. Thymidine does not compete with MTX for transport into the cell, and it is directly converted to 
thymidine monophosphate by the salvage enzyme thymidine kinase $[65,66]$. Exogenously supplied thymidine negates TYMS inhibition by increasing intracellular thymidine pools for subsequent DNA synthesis by up to 6-fold [67]. MTX elimination is unaffected by thymidine. Thymidine's rapid clearance requires continuous infusion at a dose of $8 \mathrm{~g} / \mathrm{m}^{2}$ per day IV. However, the NCI's investigational new drug protocol is closed, and thymidine is no longer available in the United States.

Glutamate carboxypeptidase $\left(\mathrm{CPDG}_{2}\right.$, carboxypeptidase $\mathrm{G}_{2}$, glucarpidase, EC 3.4.17.11) is a bacteria-derived metalloenzyme that directly cleaves methotrexate into inactive DAMPA and glutamate (Figure 3). Its dimerized structure contains two domainsa beta-sheet dimer interaction site and a di-zinc catalytic domain [68]. Its optimum $\mathrm{pH}$ is 7.0-7.5, compatible with human physiology [70]. The typical dose is 50 units/kg IV given over 5 minutes. Administration of $\mathrm{CPDG}_{2}$ produces a rapid reduction of serum MTX concentrations by $95-99 \%$ within 15 minutes $[13,15]$. Since DAMPA is known to cross-react with most commercial MTX immunoassays, persistently elevated concentrations of MTX may be reported if an immunologically based assay is used after $\mathrm{CPDG}_{2}$ administration [15]. Therefore, high-performance liquid chromatography must be employed to determine actual serum MTX concentrations. $\mathrm{CPDG}_{2}$ has a 15 -fold higher affinity for MTX $\left(\mathrm{K}_{\mathrm{m}}=8 \times 10^{-6} \mathrm{M}\right)$ than for leucovorin $\left(\mathrm{K}_{\mathrm{m}}=1.2 \times 10^{-4} \mathrm{M}\right)$, although affinity for folate is similar $\left(\mathrm{K}_{\mathrm{m}}=4 \times 10^{-6} \mathrm{M}\right)[69,70]$. Despite this, many protocols recommend that leucovorin not be administered for 2 hours before and for up to 2 hours after $\mathrm{CPDG}_{2}$ is provided. A second, identical 50 units $/ \mathrm{kg}$ dose of $\mathrm{CPDG}_{2}$ may be administered 48 hours after the first dose because CPDG $_{2}$ acts only on extracellular MTX, and redistribution of MTX from the intracellular compartment may occur. This slow efflux of intracellular MTX mandates continued leucovorin therapy (many protocols suggest continuing leucovorin $250 \mathrm{mg} / \mathrm{m}^{2}$ IV every 6 hours until 48 hours after the second dose of carboxypeptidase). Then, leucovorin is continued until the MTX concentration is $<50 \mathrm{nmol} / \mathrm{L}$ $(0.05 \mu \mathrm{mol} / \mathrm{L})$. Intrathecal $\mathrm{CPDG}_{2}$ has been administered with complete patient recovery in cases of inadvertent IT MTX administration [71,72].

$\mathrm{CPDG}_{2}$ is available in the United States on a compassionateuse basis from the NCI and under an open-label treatment protocol (ClinicalTrials.gov identifier: NCT00481559). A doubleblind, placebo-controlled trial is ongoing at the M.D. Anderson Cancer Center (Houston, Texas) (ClinicalTrials.gov identifier: NCT00424645). Emergency inquiries and supply details might also be directed to AAIPharma: 866-918-1731 (intravenous emergencies) or Protherics Inc: 888-327-1027 (intrathecal emergencies). Specialty cancer centers that may have access to this antidote might also serve as a resource. Common adverse effects include

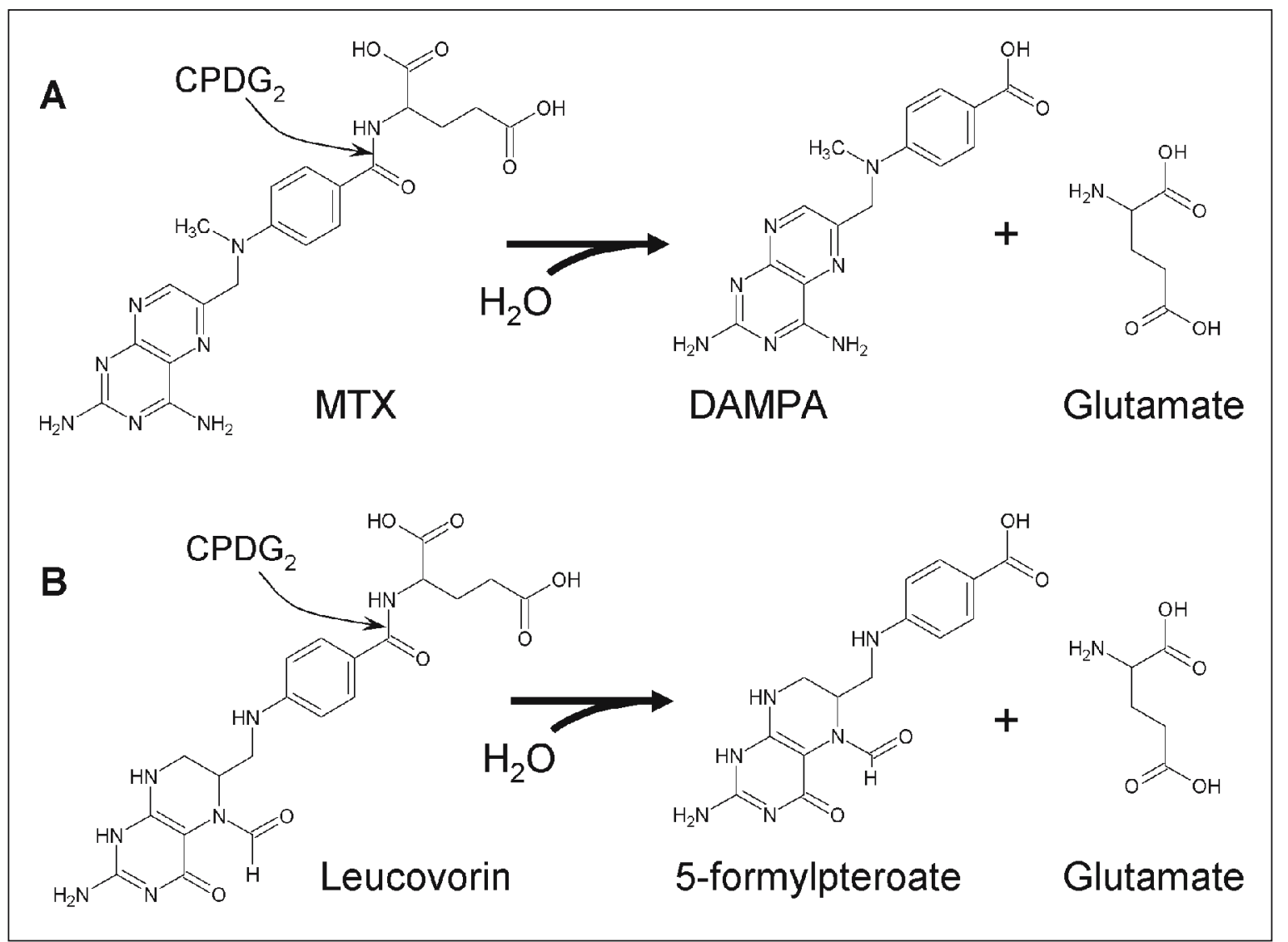

Figure 3: $C P D G_{2}$ hydrolysis of $(A)$ methotrexate or (B) leucovorin to DAMPA (4-amino-4-deoxy-10-methylpteroic acid) or 5-formylpteroate plus glutamate. 
feeling of warmth, tingling fingers, flushing, shaking, burning of the face and extremities, head pressure, and pruritus $[15,66]$.

\section{Is there a role for extracorporeal drug removal?}

High-flux hemodialysis or charcoal hemoperfusion may be indicated for patients at risk for developing MTX toxicity despite leucovorin treatment, particularly those with worsening renal function. Clinically significant quantities of MTX can be removed by high-flux hemodialysis, charcoal hemoperfusion, or combination of the two [73-77]. MTX redistribution from the cellular compartment may result in a rebound from the mean 53\% to $76 \%$ reductions in MTX concentrations achieved, and require repeat dialysis sessions [13]. Peritoneal dialysis is not effective, as it clears MTX only in the first hour of the exchange and has negligible effect on serum concentrations $[78,79]$. Carboxypeptidase (see above) is largely replacing the need for dialysis, although dialysis may be required in the setting of severe renal dysfunction, if $\mathrm{CPDG}_{2}$ is unavailable, or while awaiting its delivery.

\section{CASE CONCLUSION}

The patient initially received saline hydration and leucovorin ( $1500 \mathrm{mg} / \mathrm{m}^{2}$ every 6 hours), although urinary alkalinization with sodium bicarbonate was insufficient $(\mathrm{pH}<7)$. The PCC recommended enhanced urinary alkalinization and either high-flux hemodialysis or charcoal hemoperfusion pending determination of $\mathrm{CPDG}_{2}$ availability and delivery. The PCC assisted in obtaining $\mathrm{CPDG}_{2}(50 \mathrm{U} / \mathrm{kg})$ on a compassionate-use basis, which was administered at 68 hours post-onset of MTX infusion (Figure 1). The MTX concentration measured by immunoassay dropped by approximately 90\% (HPLC unavailable) to $6.25 \mu \mathrm{mol} / \mathrm{L}$ (6.25 $\times$ $10-6 \mathrm{M})$. A second identical $\mathrm{CPDG}_{2}$ dose was given 48 hours later. The patient's creatinine peaked at $2.95 \mathrm{mg} / \mathrm{dL}(260.8 \mu \mathrm{mol} / \mathrm{L})$. Within 24 hours of $\mathrm{CPDG}_{2}$ administration, renal and hepatic dysfunction stabilized and began trending towards normal. Visual symptoms rapidly resolved, and his abdominal pain improved over several days. Ultimately, he was discharged 28 days after the initial MTX infusion and was able to undergo a subsequent chemotherapy cycle.

The authors have no financial interest in any commercial products mentioned nor the companies that produce them.

\section{REFERENCES}

1. Farber S, Diamond LK, Mercer RD, Sylvester RF Jr, Wolff JA. Temporary remissions in acute leukemia in children produced by folic acid antagonist, 4-aminopteroyl-glutamic acid (aminopterin). N Engl J Med 1948;238(23):787-793.

2. Sacks MS, Bradford GT, Schoenbach EB. The response of acute leukemia to the administration of the folic acid antagonists, aminopterin and a-methopterin; report of 14 cases. Ann Intern Med 1950;32(1):80-115.
3. Farber S. Some observations on the effect of folic acid antagonists on acute leukemia and other forms of incurable cancer. Blood 1949;4(2):160-167.

4. Meyer LM, Miller FR, Rowen MJ, Bock G, Rutzky J. Treatment of acute leukemia with amethopterin (4-amino, 10methyl pteroyl glutamic acid). Acta Haematol 1950;4(3):157-167.

5. Li MC, Hertz R, Spencer DB. Effect of methotrexate therapy upon choriocarcinoma and chorioadenoma. Proc Soc Exp Biol Med 1956;93(2):361-366.

6. Abel EA. Immunosuppressant and cytotoxic drugs: Unapproved uses or indications. Clin Dermatol

2000;18(1):95-101.

7. Kawai S. Current drug therapy for rheumatoid arthritis. J Orthop Sci 2003;8(2):259-263.

8. Tanaka T, Hayashi H, Kutsuzawa T, Fujimoto S, Ichinoe K. Treatment of interstitial ectopic pregnancy with methotrexate: Report of a successful case. Fertil Steril 1982;37(6):851-852.

9. Lipscomb GH. Medical therapy for ectopic pregnancy. Semin Reprod Med 2007;25(2):93-98.

10. Christin-Maitre S, Bouchard P, Spitz IM. Medical termination of pregnancy. N Engl J Med 2000;342(13):946-956.

11. Remberger M, Ringden O. Similar outcome after unrelated allogeneic peripheral blood stem cell transplantation compared with bone marrow in children and adolescents. Transplantation 2007;84(4):551-554.

12. Srinivasan R, Takahashi Y, McCoy JP, et al., Overcoming graft rejection in heavily transfused and allo-immunised patients with bone marrow failure syndromes using fludarabinebased haematopoietic cell transplantation. Br J Haematol 2006;133(3):305-314.

13. Widemann BC, Balis FM, Kempf-Bielack B, et al. Highdose methotrexate-induced nephrotoxicity in patients with osteosarcoma. Cancer 2004;100(10):2222-2232.

14. Bleyer WA. The clinical pharmacology of methotrexate: New applications of an old drug. Cancer 1978;41(1):36-51.

15. Buchen S, Ngampolo D, Melton RG, et al. Carboxypeptidase G2 rescue in patients with methotrexate intoxication and renal failure. Br J Cancer 2005;92(3):480-487.

16. Evans WE, Crom WR, Abromowitch M, et al. Clinical pharmacodynamics of high-dose methotrexate in acute lymphocytic leukemia. Identification of a relation between concentration and effect. N Engl J Med 1986;314(8):471-477.

17. Ruggiero A, Conter V, Milani M, et al. Intrathecal chemotherapy with antineoplastic agents in children. Paediatr Drugs 2001;3(4):237-246.

18. Bleyer WA. Clinical pharmacology of intrathecal methotrexate. II. An improved dosage regimen derived from agerelated pharmacokinetics. Cancer Treat Rep 1977;61(8):1419-1425.

19. Roenigk HH Jr Auerbach R, Maibach H, Weinstein G, Lebwohl M. Methotrexate in psoriasis: Consensus conference. J Am Acad Dermatol 1998;38(3):478-485.

20. Borchers AT, Keen CL, Cheema GS, Gershwin ME. The use of methotrexate in rheumatoid arthritis. Semin Arthritis Rheum 2004;34(1):465-483. 
21. Moisa A, Fritz P, Benz D, Wehner HD. Iatrogenicallyrelated, fatal methotrexate intoxication: A series of four cases. Forensic Sci Int 2006;156(2-3):154-157.

22. Goldsmith P, Roach A. Methods to enhance the safety of methotrexate prescribing. J Clin Pharm Ther 2007;32(4):327-331.

23. Dervieux T, Furst D, Lein DO, et al. Polyglutamation of methotrexate with common polymorphisms in reduced folate carrier, aminoimidazole carboxamide ribonucleotide transformylase, and thymidylate synthase are associated with methotrexate effects in rheumatoid arthritis. Arthritis Rheum 2004; $50(9): 2766-2774$.

24. Genestier L, Paillot R, Quemeneur L, Izeradjene K, Revillard $J P$. Mechanisms of action of methotrexate. Immunopharmacology 2000;47(2-3):247-257.

25 . Treon SP, Chabner BA. Concepts in use of high-dose methotrexate therapy. Clin Chem 1996;42(8 Pt 2):1322-1329.

26. Joerger, $M$, Huitema $A D$, van den Bongard $H J$, et al. Determinants of the elimination of methotrexate and 7hydroxy-methotrexate following high-dose infusional therapy to cancer patients. Br J Clin Pharmacol 2006;62(1):71-80.

27. Comandone A, Passera R, Boglione A, Tagini V, Ferrari S, Cattel L. High dose methotrexate in adult patients with osteosarcoma: Clinical and pharmacokinetic results. Acta Oncol 2005;44(4):406-411.

28. Bore P, Bruno R, Lena N, Favre R, Cano JP. Methotrexate and 7-hydroxy-methotrexate pharmacokinetics following intravenous bolus administration and high-dose infusion of methotrexate. Eur J Cancer Clin Oncol 1987;23(9):1385-1390.

29. Thompson PA, Murry DJ, Rosner GL, et al. Methotrexate pharmacokinetics in infants with acute lymphoblastic leukemia. Cancer Chemother Pharmacol 2007;59(6):847-853.

30. Skärby T, Jönsson P, Hjorth L, et al. High-dose methotrexate: On the relationship of methotrexate elimination time vs renal function and serum methotrexate levels in 1164 courses in 264 Swedish children with acute lymphoblastic leukaemia (ALL). Cancer Chemother Pharmacol 2003;51(4):311-320.

31. Bostrom BC, Erdmann GR, Kamen BA. Systemic methotrexate exposure is greater after intrathecal than after oral administration. J Pediatr Hematol Oncol 2003;25(2):114-117.

32. Hartman SC, Buchanan JM. Biosynthesis of the purines. XXVI. The identification of the formyl donors of the transformylation reactions. J Biol Chem 1959;234(7):1812-1816.

33. Anguera MC, Suh JR, Ghandour H, Nasrallah IM, Selhub J, Stover PJ. Methenyltetrahydrofolate synthetase regulates folate turnover and accumulation. J Biol Chem

2003;278(32):29856-29862.

34. Lingg RM, Hempel G, Rots MG, Van Zantwijk CH, Boos J, Kaspers GJ. Effects and interaction of 7-hydroxy methotrexate and methotrexate in leukaemic cells ex vivo measured by the thymidylate synthase inhibition assay. Cancer Chemother Pharmacol 2005;56(3):322-327.

35. Allegra CJ, Chabner BA, Drake JC, Lutz R, Rodbard D, Jolivet J. Enhanced inhibition of thymidylate synthase by methotrexate polyglutamates. J Biol Chem 1985;260(17):9720-9726.
36. Uga H, Kuramori $C$, Ohta A, et al. A new mechanism of methotrexate action revealed by target screening with affinity beads. Mol Pharmacol 2006;70(5):1832-1839.

37. Harned TM, Mascarenhas L. Severe methotrexate toxicity precipitated by intravenous radiographic contrast. J Pediatr Hematol Oncol 2007;29(7):496-499.

38. Weisman MH, Furst DE, Park GS, et al. Risk genotypes in folate-dependent enzymes and their association with methotrexate-related side effects in rheumatoid arthritis. Arthritis Rheum 2006;54(2):607-612.

39. Jahnke K, Korfel A, Martus P, et al. High-dose methotrexate toxicity in elderly patients with primary central nervous system lymphoma. Ann Oncol 2005;16(3):445-449.

40. Cannon GW. Methotrexate pulmonary toxicity. Rheum Dis Clin North Am 1997;23(4):917-937.

41. Erasmus JJ, McAdams HP, Rossi SE. Drug-induced lung injury. Semin Roentgenol 2002;37(1):72-81.

42. Alarcón GS, Kremer JM, Macaluso M, et al. Risk factors for methotrexate-induced lung injury in patients with rheumatoid arthritis. A multicenter, case-control study. Methotrexate-Lung Study Group. Ann Intern Med 1997;127(5):356-364.

43. Shapiro CL, Yeap BY, Godleski J, et al. Drug-related pulmonary toxicity in non-Hodgkin's lymphoma. Comparative results with three different treatment regimens. Cancer 1991;68(4):699-705.

44. Vezmar S, Becker A, Bode U, Jaehde U. Biochemical and clinical aspects of methotrexate neurotoxicity. Chemotherapy 2003;49(1-2):92-104.

45. Weiss HD, Walker MD, Wiernik PH. Neurotoxicity of commonly used antineoplastic agents (first of two parts). $N$ Engl J Med 1974;291(2):75-81.

46. Norrell H, Wilson CB, Slagel DE, Clark DB. Leukoencephalopathy following the administration of methotrexate into the cerebrospinal fluid in the treatment of primary brain tumors. Cancer 1974;33(4):923-932.

47. Rubinstein LJ, LJ, Herman MM, Long TF, Wilbur JR. Disseminated necrotizing leukoencephalopathy: A complication of treated central nervous system leukemia and lymphoma. Cancer 1975;35(2):291-305.

48. Fotoohi K, Skärby T, Söderhäll S, Peterson C, Albertioni F. Interference of 7-hydroxymethotrexate with the determination of methotrexate in plasma samples from children with acute lymphoblastic leukemia employing routine clinical assays. $J$ Chromatogr B Analyt Technol Biomed Life Sci 2005;817(2):139-144.

49. Nirenberg A, Mosende C, Mehta BM, Gisolfi AL, Rosen G. High-dose methotrexate with citrovorum factor rescue: Predictive value of serum methotrexate concentrations and corrective measures to avert toxicity. Cancer Treat Rep 1977;61(5):779-783.

50. Proudfoot AT, Krenzelok EP, Vale JA. Position paper on urine alkalinization. J Toxicol Clin Toxicol 2004;42(1):1-26.

51. Sasaki K, Tanaka J, Fujimoto T. Theoretically required urinary flow during high-dose methotrexate infusion. Cancer Chemother Pharmacol 1984;13(1):9-13. 
52. Sand TE, Jacobsen S. Effect of urine $\mathrm{pH}$ and flow on renal clearance of methotrexate. Eur J Clin Pharmacol

1981;19(6):453-456.

53. Christensen ML, Rivera GK, Crom WR, Hancock ML, Evans WE. Effect of hydration on methotrexate plasma concentrations in children with acute lymphocytic leukemia. J Clin Oncol 1988;6(5):797-801.

54. Sauberlich HE, Baumann CA. A factor required for the growth of Leuconostoc citrovorum. J Biol Chem

1948; 176(1):165-173.

55. Schoenbach EB, Greenspan EM, Colsky J. Reversal of aminopterin and amethopterin toxicity by citrovorum factor. J Am Med Assoc 1950;144(18):1558-1560.

56. Jaffe N, Jorgensen K, Robertson R, George M, Letvak L, Barrett G. Substitution of l-leucovorin for d,l-leucovorin in the rescue from high-dose methotrexate treatment in patients with osteosarcoma. Anticancer Drugs 1993;4(5):559-564.

57. Bleyer WA. New vistas for leucovorin in cancer chemotherapy. Cancer 1989;63(6 Suppl):995-1007.

58. Schilsky RL, Ratain MJ. Clinical pharmacokinetics of high-dose leucovorin calcium after intravenous and oral administration. J Natl Cancer Inst 1990;82(17):1411-1415.

59. Bleyer WA. Methotrexate: Clinical pharmacology, current status and therapeutic guidelines. Cancer Treat Rev

1977;4(2):87-101.

60. Flombaum CD, Meyers, PA. High-dose leucovorin as sole therapy for methotrexate toxicity. J Clin Oncol

1999;17(5):1589-1594.

61. Pinedo HM, Zaharko DS, Bull JM, Chabner BA. The reversal of methotrexate cytotoxicity to mouse bone marrow cells by leucovorin and nucleosides. Cancer Res 1976;36(12):4418-4424.

62. Jardine LF, Ingram LC, Bleyer WA. Intrathecal leucovorin after intrathecal methotrexate overdose. J Pediatr Hematol Oncol 1996; 18(3):302-304.

63. Trinkle R, Wu JK. Intrathecal leukovorin after intrathecal methotrexate overdose. J Pediatr Hematol Oncol

1997;19(3):267-269.

64. Grem JL, King SA, Sorensen JM, Christian MC. Clinical use of thymidine as a rescue agent from methotrexate toxicity. Invest New Drugs 1991;9(3):281-290.

65. Graham-Cole CL, Thomas HD, Taylor GA, et al. An evaluation of thymidine phosphorylase as a means of preventing thymidine rescue from the thymidylate synthase inhibitor raltitrexed. Cancer Chemother Pharmacol 2007;59(2):197-206.

66. Widemann BC, Adamson PC. Understanding and managing methotrexate nephrotoxicity. Oncologist 2006;11(6):694-703.

67. Howell SB, Ensminger WD, Krishan A, Frei E III.

Thymidine rescue of high-dose methotrexate in humans. Cancer Res 1978;38(2):325-330.

68. Rowsell S, Pauptit RA, Tucker AD, Melton RG, Blow DM, Brick P. Crystal structure of carboxypeptidase G2, a bacterial enzyme with applications in cancer therapy. Structure 1997;5(3):337-347.

69. Albrecht AM, Boldizsar E, Hutchison DJ. Carboxypeptidase displaying differential velocity in hydrolysis of methotrexate, 5-methyltetrahydrofolic acid, and leucovorin. J Bacteriol 1978;134(2):506-513.

70. Sherwood RF, Melton RG, Alwan SM, Hughes P. Purification and properties of carboxypeptidase G2 from Pseudomonas sp. strain RS-16. Use of a novel triazine dye affinity method. Eur J Biochem 1985;148(3):447-453.

71. Widemann BC, Balis FM, Shalabi A, et al. Treatment of accidental intrathecal methotrexate overdose with intrathecal carboxypeptidase G2. J Natl Cancer Inst 2004;96(20):1557-1559.

72. O'Marcaigh AS, Johnson CM, Smithson WA, et al. Successful treatment of intrathecal methotrexate overdose by using ventriculolumbar perfusion and intrathecal instillation of carboxypeptidase G2. Mayo Clin Proc 1996;71(2):161-165.

73. Saland JM, Leavey PJ, Bash RO, Hansch E, Arbus GS, Quigley R. Effective removal of methotrexate by high-flux hemodialysis. Pediatr Nephrol 2002;17(10):825-829.

74. Wall SM, Johansen MJ, Molony DA, DuBose TD Jr, Jaffe N, Madden T. Effective clearance of methotrexate using high-flux hemodialysis membranes. Am J Kidney Dis 1996;28(6):846-854.

75. Relling MV, Stapleton FB, Ochs J, et al. Removal of methotrexate, leucovorin, and their metabolites by combined hemodialysis and hemoperfusion. Cancer 1988;62(5):884-888.

76. Molina R, Fabian C, Cowley B Jr. Use of charcoal hemoperfusion with sequential hemodialysis to reduce serum methotrexate levels in a patient with acute renal insufficiency. Am J Med 1987;82(2):350-352.

77. Djerassi I, Ciesielka W, Kim JS. Removal of methotrexate by filtration-adsorption using charcoal filters or by hemodialysis. Cancer Treat Rep 1977;61(4):751-752.

78. Ahmad S, Shen FH, Bleyer WA, Methotrexate-induced renal failure and ineffectiveness of peritoneal dialysis. Arch Intern Med 1978;138(7):1146-1147.

79. Diskin CJ, Stokes TJ, Dansby LM, Radcliff L, Carter TB. Removal of methotrexate by peritoneal dialysis and hemodialysis in a single patient with end-stage renal disease. Am J Med Sci 2006;332(3):156-158.

80. Toone JR, Applegarth DA, Coulter-Mackie MB, James ER. Recurrent mutations in P- and T-proteins of the glycine cleavage complex and a novel T-protein mutation (N145I): a strategy for the molecular investigation of patients with nonketotic hyperglycinemia (NKH). Mol Genet Metab 2001;72(4):322-325.

81. Anguera MC, Suh JR, Ghandour H, Nasrallah IM, Selhub J, Stover PJ. Methenyltetrahydrofolate synthetase regulates folate turnover and accumulation. J Biol Chem

2003;278(32):29856-29862.

82. Silverman M, Keresztesy JC, Koval GJ, Gardiner RC. Citrovorum factor and the synthesis of formylglutamic acid. J Biol Chem 1957;226(1):83-94. 